\title{
Positive and Negative Politeness: A Cross-Cultural Study of Responding to Apologies by British and Pakistani Speakers
}

\author{
Tahir Saleem ${ }^{1} \&$ Uzma Anjum ${ }^{1}$ \\ ${ }^{1}$ Air University, Islamabad, Pakistan \\ Correspondence: Tahir Saleem, Air University, Islamabad, Pakistan. E-mail: tahir.saleem@ucp.edu.pk
}

Received: March 28, 2018 Accepted: May 2, 2018 Online Published: May 23, 2018

doi:10.5539/ijel.v8n5p71 URL: https://doi.org/10.5539/ijel.v8n5p71

\begin{abstract}
Speech etiquette is an essential part of culture, behavior and human communication. Based upon a theoretical framework of politeness and face-threatening acts (FTAs), this study investigates cultural differences in apology responses (ARs) moderated by the threatened face type and the relationship between participants. A discourse completion test, consists of twelve situations is used for data collection. The data was collected from 150 Pakistani Urdu speakers (teachers, doctors, army personals, lawyers, journalists and academicians) working in different institutions and 30 British English speakers (faculty members of English Department, Coventry University, UK, Leeds University, UK and British Association of Applied Linguistics members). The findings reveal that Pakistanis are found using more positive face threatening apology responses (Acceptance and Acknowledgment) including Absolution, Dismissal, Intensifiers, and Acknowledgement with Thanking, Advice, and Suggestion, than British speakers who tend to use both positive FTAs (Acceptance) based on Absolution "That's Okay", and Dismissal "no worries at all but be careful next time" and negative FTAs based on Evasion with Deflection and Evasion with Thanking. The findings further illustrate that the understanding and demonstration of politeness and face in conversation functions are susceptible to cultural and sociolinguistic variations.
\end{abstract}

Keywords: speech etiquette, culture, behavior, politeness and negative politeness, apology responses

\section{Introduction}

Different nations in the world possess their own particular cultures which demonstrate some "universalities and particularities" (Wei, 2009). Culture and language are closely interconnected in a way that sociocultural conventions designate our way of thinking and speaking (Sapir, 1949; Whorf, 1956, as cited in Liu, 1995). Consequently, communicative patterns of individuals in speech behaviors are cultural specific and are quite unique in its own. Intercultural communication studies have indicated that people from different communities construe linguistic expressions of cultural "other" according to their own local sociocultural standards or according to the social rules of their own communal configuration (Wu \& Wang, 2016).

In Pakistani context, Rahman (1998) opines that most middle level professional people, doctors, engineers, college and university lecturers, lawyers and civil servants use the kind of English that is formal, bureaucratic, somewhat old-fashioned and full of Pakistani idiomatic constructions, loan words from Pakistani languages and distinctive grammatical constructions. Their pronunciation too is influenced largely by their first languages. Beebe (1988) calls this type of practice "sociocultural transfer," and identified it as one of the major problems preventing L2 learners from communicating effectively in the target language. Therefore, interlocutors should attend to cultural mode of the message in addition to its form. In other words, a successful communication demands grammatical as well as sociolinguistic competence (Richards, 1980; Canale \& Swain, 1980). The notion of speech acts cannot be denied for the investigation of cultural and linguistic differences and commonalities between two nations. The speech act of apology has been given immense attention in the recent years for the investigation of speech acts and politeness bahaviour of the different language speakers.

Wouk (2006), Sultana and Khan (2014) analyze that numerous researches on apologies have merely put forward major issues concerning "apology as a speech act" while including queries such as keeping in view the cultural dissimilarities, what are the differences in the ways through which an apology is carried out, and in certain given situations, what are the certain strategies being employed by the interlocutors, when an apology is to be accurate and appropriate, what certain semantic formulas have been employed, what are particular sorts of apology terms 
that have been used, and also how an apology is intensified, minimized, upgraded, and strengthened. However, the vital aspect of how people belonging to differing cultures as well as languages express themselves while responding to an apology is missing in the previous researches. So, ARs i.e. Apology Responses are not among the major concerns of the investigations. The major focus of prior studies such as that of Agyekum (2006, as cited in Adrefiza \& Jones, 2013) has been mainly on analyzing the performance of various apologies, rather than on evaluating the reaction and response to these apologies on the part of the people belonging to certain cultures and speaking differing languages. Bataineh and Bataineh (2008, as cited in Adrefiza \& Jnoes, 2013) argue that if the vital aspect of the reaction of interlocutors towards an apology is given due importance in pragmatic investigations, it would not only supplement Pragmatics, but it would also be a prospective area for future research as this aspect of participant's reaction to the apologies would throw light not only on Pragmatics, but also on the patterns through which speech acts are realized across cultures and languages. Involving this vital aspect, pragmatic studies can also detect numerous socio-cultural features from various cultures and languages. In short, this could serve as a crucial area for future investigations.

There has been no study conducted in the realization of apology responses of Pakistani Urdu and British English speakers. This study aims to investigate how Pakistani Urdu and British English speakers realize the speech act of apology response. The main focus of the study is how both Pakistani Urdu and British English speakers adhere to some of the universal principles of politeness strategies and face works. In addition, English is a Lingua franca, as it is the most dominant language used quite regularly in official documents as well as in daily communication in Pakistan (Rahman, 1998). The study highlights both British English and Pakistani Urdu speakers' realization of apology responses, focusing specifically at cultural commonalities and difference in the use of politeness patterns and linguistic expressions which are essential characteristics of sociocultural aspects. A wide research gap in the existing literature is present and this study has been attempted to fill in this.

\section{Literature Review}

In recent years, there has been immense interest in investigating Sociocultural transfer i.e. the phenomena of one's use of own cultural norms of speech acts into one's learned L2 language (Afghari , 2007; Wannaruk, 2008; Chang, 2009; Allami \& Naeimi, 2011; Bu, 2011; Bou-Franch, 2012; Hashemian, 2012; Tavakoli \& Shirinbakhsh, 2014; Yarahmad \& Fathi, 2015; Jiang, 2015; Agyekum; 2015; Loutfi, 2016). It creates, which Thomas $(1983,1984)$ termed as Socio-pragmatic failures, that is defined as the "miss-match, which arises from the culturally different assessments within the social parameters of affecting linguistic size, choice of the imposition, the social distance between the speaker and hearer and the relative rights and obligations, etc." (Thomas, 1984, p. 226)

According to Blum-Kulka, House, and Kasper (1989), one of the most compelling notions in developing sociocultural competence is the idea of speech acts. The reason behind this notion is the application of these speech acts in daily conversation (Searle, 1975). Variance in verbalization and conceptualization across cultures and languages has been one of the quite significant aspects of speech (Wierzbicka, 1994; Cohen, 2006; Sultana \& Khan, 2014).

In fact, researches on apology conversation act have been performed in solitude, without giving the due interest to the interlocutor's potential responses. Although a few researchers, such as Agyekum (2006), Owen (1983), Robinson (2004), and Holmes (1990, 1995), have involved a few pragmatic apology responses in their research, the investigations still stay imperfect and undetermined with regards to language techniques and socio-pragmatic intricacies and technicalities. These studies have been handled more as a succeeding research instead of a main focus of the research, showing that scholars' interest to the subject still continues to be restricted and incomprehensive in characteristics (McCullough, 2000).

The act of ARs continues to be complicated as it represents not only language factors, but also emotional and social components. Situational factors, Individual factors, and the interaction of situation and personality are significant aspects which perform significant roles in its understanding (McCullough, Pargament, \& Thoresen, 2000). Observing that many scholars of psychology have a systematic curiosity in analyzing such an act, a number of researchers (Gorsuch, 1988; Goffman, 1971) have also tried to link the corrective interchanges (apologizing and responding) to spiritual concepts which allow the upset individuals to pardon the violators.

Three features that may conform to apologies: (a) appreciation; (b) relief; and (c) minimization. Expressions such as: "That's OK", "You're welcome", "Think nothing about it", "That's all right", are quite common plummeting terms expressed in US communication while executing the reaction (Goffman, 1971). These terms specify an agreement of repent, though "all right" or OK" without deictic "it" or "that's" is known as an identification of an apology (Owen, 1983). Other terms such as "It's nothing", "Never mind", and "No problem" 
can be viewed as an apology acceptance strategy as they indicate the speaker's fulfilment over the wrongdoing. Later analysis on ARs, by Holmes (1995), Robinson (2004), and Adrefiza and Jones (2013), for example, classified the above terms into convenience, admiration, and minimization. Other possible responses were included: acknowledgment, evasion and rejection (Holmes, 1995). The use of pragmalinguistic gadgets can offer the use of either convenience or minimization in conversation act expression (Adrefiza \& Jones, 2013).

Holmes (1995) notices that reactions to regret can be demonstrated in different means, varying from unobtrusive to several types of language terms, and sites apology reaction techniques into a few extensive groups. These terms are: Agree to, Recognize, Avoid, and Decline. Absolution "That's alright" or "That's okay" was the best suggested reply to repent, especially in British and U. S conversation (Robinson, 2004; Owen, 1983). Acknowledgment has been also referred as AR strategy by Robinson (2004), but such a response to apology is often expressed through non-verbal actions, and no particular verbal utterance is recognized to indicate this response strategy including shrugging as well.

As mentioned earlier, the absolution "That's alright" entails a deictic phrase as "That's" and an appraisal such as "alright" or "OK". Further, the deictic phrase may not correspond with speech act of apology, but certainly to the wrongdoing that is communicated by the apology. In other conditions, the assessment term "alright" or "OK" generally symbolizes the respondent's assessment of the wrongdoing, displaying that the offense is not regarded as serious, and is finally dismissed. Further, the expressions based on absolution opinion indicate the respondent's concern with the offender's position that has triggered an offence. Actually, in the respondent's viewpoint no offence has occurred, thus the solidarity and stability still be successful (Robinson, 2004).

To put it simply, prior studies have targeted mostly on the production of regret, without giving enough attention to how people from various social background and "languages" respond and react to the regret. Not only can research into this matter enhance the pragmatic literature, but they can be a prospective area for further research, highlight pragmatics and conversation act understanding styles across "languages" and societies.

\section{Methodology}

This data-oriented study is based on quantitative approach to investigate the apology responses of British English and Pakistani Urdu speakers in interactive situations. For data collection, a Discourse Completion Tests (DCT), having 12 items, is developed. We personally explained and administered the DCT. All participant responses were analyzed using (SPSS-20) statistical software and summary narrative methods in order to present a realistic description of British English and Pakistani Urdu speakers ARs.

\subsection{Population and Sample}

The target population of this study was the academicians, teachers, lawyers, doctors, engineers, journalists, and army personals who have studied English as a subject till graduation. The participants were selected using purposive, convenience, non-random sampling procedures from different public sector organizations and institutions of capital cities of provinces of Pakistan. The British English speakers were from Coventry University, UK, Leeds University, UK, and British Association of Applied Linguistics (BAAL) members. The sample of Pakistani Urdu speakers was comparatively homogeneous in terms of their linguistic and cultural background and academic experiences. There were both male and female respondents. The target participants were serving in different public sector organizations and institutions. The only criteria for selecting the participants from different organizations and institutions was that the respondent should be educated (at least up to the bachelor's level) and should be in a job where the official written work is carried out in Urdu language, and can respond to apology situations appropriately.

\subsection{Instrumentations}

A Discourse Completion Test (DCT), having 12 apology response scenarios, is designed to collect information from British English and Pakistani Urdu speakers. It is pertinent to mention here that speech acts data cannot be elicited naturally, as most of the studies conducted on speech acts have used DCTs as data collection tools (Olshtain \& Cohen, 1983). The nature of such information is always a make-up sort of data. So, the DCT used in the current study consists of two parts- Part A Demographic Information and Part B Apology Response Scenarios (see Appendix A). The first part is structured to gather certain indispensable information regarding demographics such as, participants' name and status, level of education, gender, and name of institution. The part B contains 12 apology response scenarios designed to gather apology responses (realization of different pragmatic patterns) by adapting those scenarios utilized in the studies of Thijjing, (2010); Bergman and Kasper, (1993); Brown, (2008); Olshtain and Cohen, (1983); Cohen, Olshtain, and Rosenstein, (1986). In the design of the apology situations, relation of imposition, sociocultural status (high, equivalent and low) and distance (close, 
equivalent, and distant) of the participants and their interlocutors is also considered. The respondents were requested to jot down responses in DCT while having considered they are interacting in real life scenarios. In order to examine the apology responses of British English and Pakistani Urdu speakers, the present study posited sociocultural variation; social distance, severity of offense and social status for each situation in DCT (see Appendix A).

\subsection{Data Collection Procedures}

Before administrating the DCT for data collection, researchers first sought the permission from the heads of the organizations and institutions selected for this study. Responses were collected from participants from Academia, Teachers, Doctors, Engineers, Lawyers, and Army personals. One instrument was used for data collection: Discourse Completion Test (DCT). The data from British English speakers were collected through e-mails. Ethical issues of the research were taken into account in gathering data. At each organization, researchers personally invited participants to take part in the Informed Consent Sessions. Participants were provided with the information related to this study and requested to participate in the study. Each participant was provided with the Informed Consent Sheet (see Appendix B) and the Discourse Completion Test. Participants who consented to take part in the research were asked to complete the Discourse Completion Test. Researchers explained to respondents that the study focuses on language use and apology acceptance strategies not the language ability. Researchers also explained each situation to the participants before they complete the DCT.

\subsection{Data Analysis Procedures}

The present study based its data analysis on Adrefiza and Jones' (2013) apology response classifications. The responses of the participants were first grouped into general strategy classifications, using language expressions with some necessary modifications regarding the objectives, politeness, and illocutionary forces. Nevertheless, in the present study, AR detailed strategies in Urdu and English are grouped as follows:

Table 1. AR framework adopted from Jones and Adrefiza (2013)

\begin{tabular}{|c|c|c|}
\hline Strategy & Estimated Expressions in English & Estimated Expression in Urdu \\
\hline \multicolumn{3}{|l|}{ Acceptance (AC) } \\
\hline Absolution & "That's OK" & لُهيكى بـ \\
\hline Dismissal & "It doesn’t matter", “Don’t worry” & 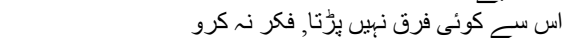 \\
\hline Formal & "I accept your apology", "I forgive you" & ميس نـ آب كى معافى قبول كى. ميس تمبيي معاف كرتا بون. \\
\hline Thanking & "Thanks (for apologizing)" & 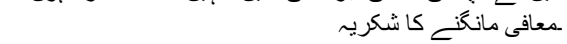 \\
\hline Intensifiers & "It's OK, really" & بلكل ثهيك بـ"- \\
\hline Requests & "Please return it as soon as possible" & بر اــمبربانى جتنا ممكن بو جلدى سـ و ايِ كر دو . \\
\hline Expressing Empathy & "I understand that stuff happens" & مين سمجهنا بوب ايسى جيزيس بو جاتى بيس- \\
\hline Expressing Emotion & "I'm disappointed" & مجه دكه بوالبه- \\
\hline Questioning/Surprise & "How could you do that to me?" & . تم بـ مير > ساته كس طرح كر سكته بو \\
\hline \multicolumn{3}{|l|}{ Acknowledgement (AK) } \\
\hline Absolution Plus & "That's OK, but ..." & 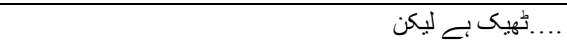 \\
\hline Dismissal Plus & "It doesn’t matter, but ..." & ... اس سح كوئى فرق نبين برنا، ليكن \\
\hline Formal Plus & "I accept your apology, but ..." & ..... مين نَّ آب كى معافى قبول كى، ليكن \\
\hline Advice/Suggestion & "You should have called me" & تمين مجهح فون كرنا جابيه تها-. \\
\hline Evaluating & "It's ridiculous", "You're horrible" & 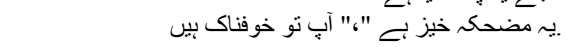 \\
\hline Accepting Promises & "OK, I believe you" & 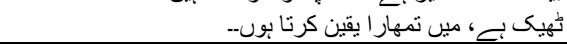 \\
\hline \multicolumn{3}{|l|}{ Evasion (EV) } \\
\hline Deflecting/Explaining & "We had lovely time anyway" & وويســ بمار > پِاس خوبصورت وقت تها \\
\hline Providing Solution & "Go home and bring the file" & كهر جاو اور فائل لـ كر آو- \\
\hline Minimization & "It's nothing. It's just a carpet" & اس كى بلكل فكر نـ كرو ـ يـ صرف اك كاربّ بـــ؟؟ \\
\hline Expressing Concerns & "Are you OK" & آٍ ثهيك بيس؟ \\
\hline Shifts of Topic & "Forget it. Let's have fun" & بهول جاو اســ- جلو مزه كرتــ بي- \\
\hline Shifts of Blame & "Bus made me to reach late" & مين بس كى وجم سـ ليث بوا بون. \\
\hline \multicolumn{3}{|l|}{ Rejection (RJ) } \\
\hline Refusals & "I don’t accept your apology" & مين آيكىى معافى قبول نبيس كرنا.. \\
\hline Description & "You destroyed may camera" & آب نـ مير ا كيمر ا خر اب كيا بـ - \\
\hline Complaining & "You are so careless" & تم برّك غير زمه دار انسان بو-- \\
\hline Warning & "I won't tell you any more secret" & ميس آب كو كوئى مزيد راز نهبي بتاون كا. \\
\hline Swearing & "You're really shit" & تم و اقعى بـ بِّو اه بو- \\
\hline Refusing Remedies & "No way, I just want the same camera" & بلكل بهى نهي- مجهم إينا كيمر ا جابيهـ- - \\
\hline Non-Apology "Sorry" & "Sorry, I can't forgive you" & معذرت، مين آب كو معاف نهي كر سكتا. \\
\hline Expressing Strong Emotions & "I'm really very angry" & ميل و اقعى مين نار اض بوب. \\
\hline Seeking for Solution & "What will you do about my laptop?" & مبر اليب ثناب كب و ايس كرو گَح- \\
\hline
\end{tabular}




\section{Results}

This section presents a quantitative analysis of data retrieved from the Discourse Completion Test (DCT) questionnaire in order to investigating positive and negative face threats of Pakistani Urdu and British English speakers. The analysis of the present study is based on Adrefiza and Jones' (2013) AR classification model; the findings of the study indicate quite a complicated linguistic phenomenon. The AR expressions are quite complex; most of the responses are not formulaic, most of them based on elaborate and unstructured expressions. The apology response techniques employed by the speakers of British English and Pakistani Urdu speakers are presented into main AR strategies, specifically focusing on the variances of main four techniques' distribution. The results are reported while highlighting the apparent similarities and differences between two groups. A detailed discussion, including a conclusion section is presented to highlight the possible relation to the apology response technique distribution, politeness pattern differences, and sociocultural variances in British English and Pakistani Urdu speakers. The table below illustrates the use of extended ARs and expressions expressed by BritE and PakU speakers. It is noticeable that Pakistani Urdu speakers tend to use more ARs than their British counterparts. AR expressions are reported and described in the following section in detail.

\section{(a) Acceptance}

Acceptance category is based upon a number of subsidiary speech act expressions. Overall, the "Acceptance" strategy is articulated based on the following terms Absolution, Dismissal, and Formal acceptance expressions. In addition, it includes other subsidiary expressions specifically, Thanking, Intensifiers, Requests, Expressing Empathy, Expressing Emotions, and Questioning/Surprise. Accumulatively, there have been used quite a good proportion of Acceptance strategies by two groups.

Nevertheless, British English speakers tend to use (60.7\%) more Acceptance strategies than Pakistani Urdu speakers (44.4\%). In the table 2 below, there is provided a comprehensive report on the use of extended AR expressions and strategies of the two groups. It is noticeable that the use of Acceptance strategies varies in term of sociocultural traits of Pakistanis. It is apparent that both British English and Pakistani Urdu speakers tend to use a variety of extended AR expressions.

Table 2. Extended ARs in acceptance classification

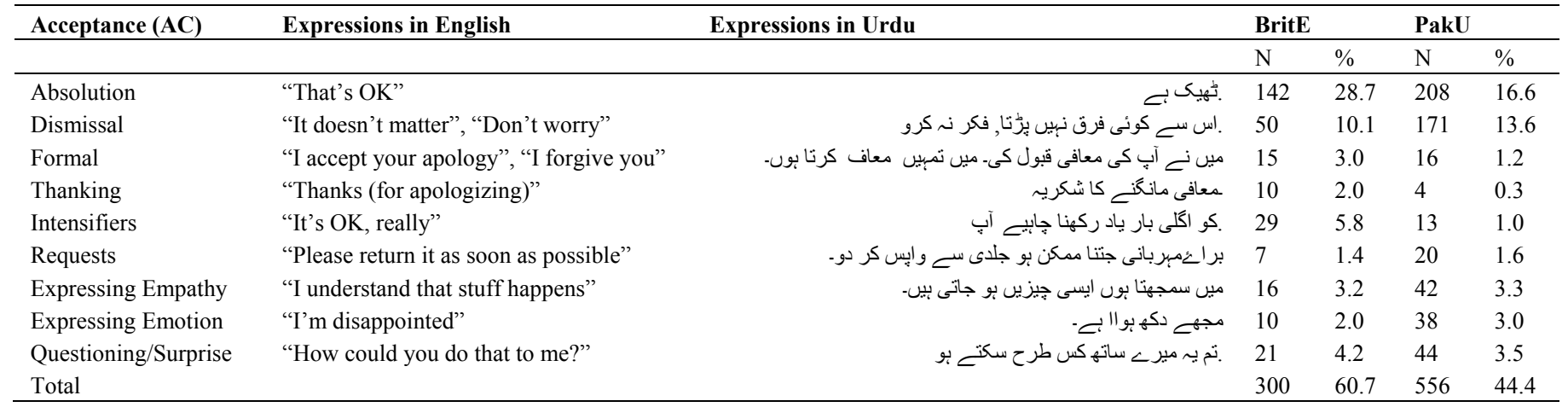

Obvious difference can be seen in Absolution, Formal, Thanking, and Questioning acceptance. Absolution occurs much more frequently in the BritE apology responses (28.7\%) than in PakU (16.6\%). Moreover, two groups tend to use Dismissal ARs quite often, there is not much difference in the ARs of two groups (BritE, and PakU) with a ratio of (10.1:13.6). Though, the rate of Acceptance is quite high in the ARs of British English speakers yet Pakistani Urdu speakers ARs are not much low. The use of Formal acceptance is also quite high in the responses of British English speakers (3.0\%). In contrast, Pakistani Urdu speakers (1.2\%) tend to use less Formal acceptance strategy. In addition, British English speakers display the use of more Thanking and Intensifiers acceptance (2.0\% and 5.8\%) than the other group. Expressing Empathy, Expressing Emotion, and Questioning/Surprise acceptance strategies are used more frequently by the two groups equally without exhibiting tangible difference.

\section{(b) Acknowledgement}

The difference in the use of extended ARs and expressions in Acknowledgement category are quite observable between the two groups. Mainly, Acknowledgement category involves ARs (Absolution, Dismissal, and Formal Acceptance) and a variety of extra ARs and expressions including Advice/Suggestion, Accepting Remedies, 
Evaluating, and Accepting Promises. Generally, Pakistani Urdu speakers tend to use more extended ARs than the British English speakers with a ratio of 27.3\%:08.5\% respectively. A detailed report of extended ARs and expressions of Acknowledgement strategy can be seen in table 3. It is evident in the table 3, Pakistani Urdu speakers tend to use more extended expressions of "Acknowledgement" than British English speakers. Pakistani Urdu speakers outnumbered in the use of "Absolution plus" category with (12.1\%), in contrast British English speakers (1.4\%) tend to use less "Absolution plus" strategy.

Table 3. Extended ARs in acknowledgement classification

\begin{tabular}{|c|c|c|c|c|c|c|}
\hline \multirow[t]{2}{*}{ Acknowledgement (AK) } & \multirow[t]{2}{*}{ Expressions in English } & \multirow[t]{2}{*}{ Expressions in Urdu } & \multicolumn{2}{|c|}{ BritE } & \multicolumn{2}{|c|}{ PakU } \\
\hline & & & $\mathrm{N}$ & $\%$ & $\mathrm{~N}$ & $\%$ \\
\hline Absolution Plus & "That's OK, but ..." & لطهيك بح ليكن & 7 & 1.4 & 152 & 12.1 \\
\hline Dismissal Plus & "It doesn't matter, but ..." & اس سـح كوئى فرق نهيل بِرنا، ليكن & 1 & 0.2 & 30 & 2.4 \\
\hline Formal Plus & "I accept your apology, but ..." & مين نـ آب كى معافى قبول كى، ليكن. & 2 & 0.4 & 34 & 2.7 \\
\hline Advice/Suggestion & "You should have called me" & تمين مجهم فون كرنا جابيح تها. & 15 & 3.0 & 84 & 6.7 \\
\hline Accepting Remedies & "That sounds good"” & 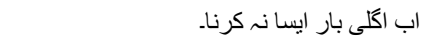 & 4 & 0.8 & 31 & 2.4 \\
\hline Evaluating & "It's ridiculous", "You're horrible" & يـ مضحكى خيز بــ "،" آب نو خوفناك بين. & 5 & 1.0 & 33 & 2.6 \\
\hline Accepting Promises & "OK, I believe you" & ثهيك بح، ميس تمهار ا يقين كرنا بوب-- & 13 & 2.6 & 83 & 6.6 \\
\hline Total & & & 47 & 9.5 & 447 & 35.7 \\
\hline
\end{tabular}

In addition, British English speakers tend to disfavor "Dismissal plus" strategy, contrarily, Pakistani Urdu speakers (2.4\%) responses are characterized by the use of "Dismissal plus" strategy. Further, the use of "Formal plus" acceptance strategy occurs more often in Pakistan Urdu speakers' responses than British English speakers ARs. The AR of "Advice/Suggestion" is another strategy that is mostly favored by Pakistani Urdu speakers (6.7\%) than British English speakers (3.0 \%). "Accepting Promises" strategy is also one of the strategies which is not used quite often by British English speakers (2.3\%), though Pakistani Urdu speakers tend to use this strategy quite often with a ratio of 6.6. The use of "Accepting Remedies" and "Evaluating" remains quite low in British English speakers' responses with a ratio of 0.8:1.0. While Pakistani Urdu speakers are found using "Accepting Remedies" and "Evaluating" strategies with a ratio of 3.0:2.6 respectively.

\section{(c) Evasion}

The use of extended expressions in ARs of two groups also exhibits some acute differences. Unlike, Acknowledgement and Rejection strategies, British English speakers (BritE) tend to use "Evasion" strategy more often than Pakistani Urdu speakers (PakU). Table 4 below demonstrates the frequency of Evasion strategy of the two groups. It is obvious from the table 4 that BritE tend to use more often Deflecting/Explaining (7.2\%), Request (6.8\%), Thanking (4.8\%), Advice/Suggestion (3.6\%) and Question/Surprise (2.8\%) than PakU. Unlike other strategies, PakU incline to use more Expressing Emotion strategy with a ratio of 0.9 than BritE. The table 3 below illustrates the results of Evasion category.

Table 4. Extended ARs in evasion classification

\begin{tabular}{|c|c|c|c|c|c|c|}
\hline Evasion (EV) & Expressions in English & Expressions in Urdu & \multicolumn{2}{|c|}{ BritE } & \multicolumn{2}{|c|}{ PakU } \\
\hline & & & $\mathrm{N}$ & $\%$ & $\mathrm{~N}$ & $\%$ \\
\hline Deflecting/Explaining & "We had lovely time anyway" & وويسه بمار > پياس خوبصورت وقت تها. & 38 & 7.6 & 83 & 6.6 \\
\hline Thanking & "Go home and bring the file" & كهر جاو اور فائل له كر آاو. & 24 & 4.8 & 3 & 0.2 \\
\hline Question/Surprise & "It's nothing. It's just a carpet" & اس كى بلكل فكر نـ كرو ـ يـ صرف اك كاريث & 14 & 2.8 & 34 & 2.7 \\
\hline Request & “Are you OK" & آّب ثهيك بي؟؟ & 34 & 6.8 & 11 & 0.8 \\
\hline Advice/Suggestion & "Forget it. Let's have fun" & بهول جاو اسحـ تجلو مزه كرنه بيس. & 18 & 3.6 & 50 & 4.0 \\
\hline Expressing Emotion & "The" & مين بس كى وجـ سـ ليث بوا بون. & 3 & 0.6 & 12 & 0.9 \\
\hline Total & & & 131 & 26.5 & 193 & 15.4 \\
\hline
\end{tabular}

\section{(d) Rejection}

Findings of the current study illustrate that the speech act of Rejection is quite complex and complicated as compared to other AR categories. It carries a number of extended speech acts and expressions based on Refusal, Description, Complaining, Warning, Swearing, Asking for Compensation, Refusing Remedies, Non-Apology "Sorry", Expressing Strong Emotions, and Seeking for Solution. The table 5 displays differences among two 
groups. Subsidiary ARs, Refusals $(0.6 \%$ and $0.5 \%)$, Description $(0.8 \%$ and $0.4 \%)$, Complaining $(0.2 \%$ and $0.6 \%)$, Warning $(0.2 \%$ and $0.3 \%)$, Asking for Compensation $(0.2 \%$ and $0.3 \%)$, Refusing Remedies $(0.0 \%$ and $0.5 \%$ ) categories are found quite often in BritE and PakU responses.

Table 5. Extended ARs in rejection classification

\begin{tabular}{|c|c|c|c|c|c|c|}
\hline \multirow[t]{2}{*}{ Rejection (RJ) } & \multirow[t]{2}{*}{ Expressions in English } & \multirow[t]{2}{*}{ Expressions in Urdu } & \multicolumn{2}{|c|}{ BritE } & \multicolumn{2}{|c|}{ PakU } \\
\hline & & & $\mathrm{N}$ & $\%$ & $\mathrm{~N}$ & $\%$ \\
\hline Refusals & "I don’t accept your apology" & ميس آبكىى معافى قبول نبيل كرتاـ. & 3 & 0.6 & 7 & 0.5 \\
\hline Description & "You destroyed may camera" & آب نـ مير ا كيمر ا خر اب كيا بـ - & 4 & 0.8 & 6 & 0.4 \\
\hline Complaining & "You are so careless" & تم برُخ غير زمه دار انسان بو-- & 1 & 0.2 & 8 & 0.6 \\
\hline Warning & "You got to face the music" & ميس آب كو كوئى مزيد راز نبيس بتاون كَا. & 1 & 0.2 & 4 & 0.3 \\
\hline Swearing & "Oh gosh! I was expecting you to do that" & 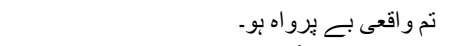 & 1 & 0.2 & 5 & 0.4 \\
\hline Asking for Compensation & "You have to replace it with the new one" & كَا/كيى اس كى جحَ نــــ والا/و الى دينا/دينى بو & 1 & 0.2 & 4 & 0.3 \\
\hline Refusing Remedies & "No way, I just want the same camera" & بلكل بهى نهبي- مجهم إينا كيمر ا جابيهـ. & 0 & 0.0 & 7 & 0.5 \\
\hline Non-Apology “Sorry” & “Sorry, I can’t forgive you" & معذرت، ميل آب كو معاف نبيل كر سكتا. & 0 & 0.0 & 0 & 0.0 \\
\hline Expressing Strong Emotions & "It's my favorit camera" & مين و اقعى مين نار اض بون. & 2 & 0.4 & 5 & 0.4 \\
\hline Seeking for Solution & "What will you do about my laptop?" & مير اليب ثاب كب و إِس كرو گَحـ. & 3 & 0.6 & 8 & 0.6 \\
\hline Total & & & 16 & 3.2 & 54 & 4.3 \\
\hline
\end{tabular}

In addition, both British English and Pakistani Urdu speakers tend to use similar proportion of Expressing Strong Emotions $(0.4 \%$ and $0.4 \%)$ and Seeking for Solution $(0.6 \%$ and $0.6 \%)$ strategies.

\section{Discussion}

The data provides an evidence about the use of AR expressions in English and Urdu revealing several phenomena of particular attention. First, ARs in English and Urdu are generally intricate. The Acceptance strategies exhibit that extended responses incorporate a mixture of conversation functions and language expression which, in most occasions, illustrate the participants' aspiration not to react candidly. The use of "That's fine if the damage is not big, you may get it fixed. It's alright, I'll clean it" and "khair he, azar karne ki koi baat nehi" are examples showing politeness. The explanation may be meant to demonstrate respect and harmony while the participants attempt to manage face risks and face damage that can then be induced on the violators. The findings are in line with the previous studies of Adreifiza and Jones (2013), Lakoff (2001), Agyekum (2006), and Holmes (1995), who recommend that both apology and apology reactions are face threatening acts in characteristics because they position both the apologist and the participant in a challenging scenario, and consequently lengthier linguistic terms are believed to be required to support this. For a lot of individuals, it is not an event for brevity (Bennett \& Earwalker, 2001). In addition, the use of more dismissal strategies by Pakistani Urdu speakers also illustrate the culture-specific apology responses because English native speakers, as mentioned by Jones and Adrfiza (2013) do not use more Dismissal strategies, as they are supposed to exhibit negative behavior of the respondents.

It is evident from the findings of present study that the Acknowledgement techniques is considered as the addressee's weak acceptance while using a blend of acceptance expressions and additional extended terms that can damage the offender's face, and may threat the interpersonal relations. Adrefiza and Jones (2013) suggest that such responses are not expressed in solitude, these responses are combined with other additional expressions such as "That's alright" (Acceptance), including a proclamation or a warning like "If I found you repeating this blunder again, I will issue you an explanation". The findings of the current study illustrate that this strategy has been expressed through quite complicated and elaborative terms, most of the ARs in this category are presented through a number of extended speech acts for example "It's alright but you should better know the path if you want to remain protocol officer" (Participant 1). "OK but I was not expecting this from you at all, now please save your words for the disciplinary committee" (Participant 3). "It's OK but walk and move carefully" (Participant 6) "It's OK but make sure it won't happen again" (Paticipant8) in English and "koi masla nai dear! Laikan zara deehan se chalo, kesi hor me na lag jana/no problem dear! But walk carefully. I'm afraid you bump into someone else as well" (Participant 3). "Men aap ki galti ko kabool karts hoon, laiken dobara esa hua to men aap ko expel kar doon g/I accept your apology, but if you repeat again, I will expel you" (Participant 9) in Urdu. These extended expressions further highlight that the participants tend to employ such expression to manifest non-absolute Acceptance; which signals that speakers of the current study do not want to allow the offender to be at appease after committing the offense. These results clearly illustrate cultural and social rules of 
speaking of two cultures, as highlighted by Jones and Adrifiza (2013), British English speakers do not use Acknowledgment strategies quite often as they tend to be weak acceptance. In contrast, Pakistanis typically, accept apology with expressions like "theek he/that's Ok" but they also add quite elaborative expressions such as indicating "Advice/Suggestion", "Accepting Remedies", "Evaluating", and "Accepting Promises".

It is clear from the findings that just like Acknowledgement category, Evasion category is also expressed by the British English and Pakistani Urdu speakers through a number of additional speech acts and expressions, which seem to have the force to damage the transgressor's negative face. As it is observed, apparently, they do not seem quite severe in nature. As mentioned earlier, the data of current study is based on the classifications of Adrefza and Jones (2013), in their study, Evasion strategy expressions are found in wide variety indicating that the results of the present study are complex. While Holmes (1995, as cited in Adrefiza \& Jones, 2013) classifies Evasion category through the expression of "Let's make another time" such kind of expression is not present in the current study. Nevertheless, almost all the Evasion ARs are carrying the similar kind of illocutionary force. For example, a workmate is late to report in the office and says "I'm sorry, I missed my bus" and colleague responds "Don't make excuses. Let's work on the report. We are running out of time". In another example friend forgets to return laptop and says "Sorry, I forgot to bring it" and friend responds to apology "It's not good habit to forget your promise but please return me ASAP". Evasion is expressed in combination of other subsidiary expressions. In another example, colleague could not reach well in time to complete a report and apologizes "Sorry dear I missed the train. Mom didn't help me to wake up early". the response of British English speaker is "Ummm oh gosh, I really wasn't expecting you to be late. Let's haste now, we got to be honest with our job". The Pakistani Urdu speaker's AR is "Aye mere Khuda, tume pata hi nai k ye kitna eham kam tha? Bhai waqat per utha karo. Or aap ko pata hona chayee $k$ ye report humari job $k$ lye kitni eham he/My God, you had no idea, how important this task was? Brother, try to wake up early. And you need to know, how important this report writing was for our job". The given examples clearly illustrate that the speakers of the current study have not demonstrated explicit or clear acceptance or rejection through their AR expressions. Alternatively, their responses provide an evidence of deflecting the responses through expressions like "Oh gosh" by BritE speaker, and "aye mere Khuda/My God" by PakU speaker, and clarifying or explaining the importance of the task as the response from BritE respondent's expression is "I really wasn't expecting you to be late", and PakU speakers uses "tume pata hi nai k ye kitna eham kam tha? / you had no idea, how important this task was?" and expressing an expectation about past event as in BritE "Let's haste now, we got to be honest with our job", and PakU response is "Or aap ko pata hona chayee k ye report humari job k lye kitni eham he/And you need to know, how important this report writing was for our job". The Evasion responses expressed here does not clearly highlight the illocutionary force of either the apology is accepted or rejected. The responses in this category are speaker-oriented not the hearer-oriented. The responses are negative in nature and remain face-threatening for the interlocutors, though an effort has been made to restore equilibrium between the speakers but addressee is not out of trouble completely.

The results show that Rejection category illustrates a few noticeable phenomena. First, this expression is mostly expressed directly for example in situation 4, junior officer copied an article from website and says "I beg pardon, forgive me this time, and assure you it won't happen again" and the response of British English speaker seems less threatening "It's pretty serious matter. I'm afraid; we may've to recommend your case to the disciplinary committee. Let me see what can be done". In contrast, Pakistani Urdu speaker's response is "Ye to crime he. HEC ne zero tolerance ki policy di hoiee he. Ap ko apni galti ka khameaza bugtna ho ga/ it's crime. HEC has given zero tolerance in this regard. You got to face the music of your blunder". The above Rejection responses from British English and Pakistani Urdu speakers are again pretty elaborative. In comparison, Pakistani Urdu speaker has demonstrated the kind of illocutionary force that is more negative and face-threatening than the British English speaker's response. It indicates again the language-specific and cultural-specific use of apology responses by Pakistani Urdu speakers. Though, British English speaker's response is also fairly long too, but it is not as face-threatening as the PakU response seems. Anyhow, these responses represent the offended person's utterance of "Warning" being commutated to the transgressor as an expression of Rejection. The speakers in the above examples are very angry and warn the offenders. The Rejection expressions mentioned illustrate the enforcement of sanctions from the offended person if the transgressor is unable to fulfil the desired objective (Kohler, 2008; Wu \& Wang, 2016). Some of the ARs of Rejection, however, are indicated along with some non-traditional remarks such as "Saying thanks to" and "Explicit apology (Non-apology "sorry"). While their utilization seems unusual in the perspective (because of their actual meanings) it is not unusual in well-known conversation. Expressions of feelings seem to depict the most of Rejection AR in Urdu and English. They illustrate that the addressees feel significantly upset and cannot suppress their feelings. The expression of "Swearing" is unavoidable and comprises the most face-threatening 
term found in the data but its use is restricted. Although irregular, its incidence alerts that the participant is seriously exacerbated. Swear terms are regularly associated with delicate topics like blasphemous or excrement concepts indicated in damn!, God!, bugger!, bloody (hell)! and shit! (Montagu, 1967; Norrick, 1987). Swearing terms usually happen when the offended person is out of control or in some negative feelings, such as in feeling disgust, annoyance, great anger or stress. sensation irritation, outrage, pressure, or great rage (Anderson \& Trudgill, 1990). The use of term "Shit" is British English speaker's data makes it certain that speaker is quite furious at the wrongdoing of the offender.

Hence, acceptance can be categorized as the offended person's disagreement with the offender's claim to have done any damage by expressing an apology, in contrast, Rejection, as can be seen in the current study, expressed indirectly, is regarded as an agreement between the offended person and the offender's claim to have done some damage. Therefore, keeping in view this reason, the harmony and equilibrium cannot be achieved.

\section{Conclusion}

Advised by Adrifiza and Jones' (2013) AR category design, the result of two groups' data demonstrates the distributions of the techniques difference and the occurrence of both positive and negative face threats. British English speakers seem to use Evasion more often than Pakistani Urdu speakers; Pakistani Urdu speakers prefer to use more often the Acknowledgment category. However, not much difference is observed in other two main techniques "Acceptance and Rejection", with British English speakers displaying a greater rate of Acceptance than PakU speakers, and PakU speakers more often realizing Rejection than British English speakers. The findings of Evasion category are not found consistent with the claims of the previous studies (Kitao \& Kitao, 2014; Owen, 1983) that both British and Pakistani cultures are fundamentally quite different from one another. According to past studies such as that of Rahman (1998), normally, Asians, such as Pakistanis are uncertain, implied, and oblique in their conversation behaviors, which at times becomes hard to understand what they actually mean. However, the results have proven that such communicative functions are not significant in their ARs, and Pakistani Urdu speakers are amazingly explicit and direct. Further, it is amazing to see British English speakers displaying a higher use of less explicit strategies. This difference may associate, at least to some degree, to a different exhibition about politeness and face concepts within the two groups in their understanding through ARs. This trend is recognized by Brown and Levinson $(1978,1987)$, who claim that the understanding and demonstration of politeness and face in conversation functions are susceptible to cultural and sociolinguistic variations. To British English participants, the implicitness may be meant to demonstrate prevention of working with the case of the apology. The different rate of Acknowledgment may also be proof of a different demonstration of politeness and face principles in the two groups' conversation styles. Allowing the perpetrator free completely, for most PakU participants, may be looked at something which causes harm to their self-worth or pride, while for most British English speakers it may be looked at the other, a way of preserving face by not sanctioning a serious offence. Therefore, PakU speakers, in a way, may agree to regret weakly in their Acknowledgements, making the violators with some type of face-threatening manifestation. Another recognizable distinction is the fact that British English speakers seem to be more negative and be less positive than PakU group in showing their apology reactions. This is indicated by the proportions at which positive reaction techniques (Acceptance and Acknowledgement) and negative reaction techniques (Evasion and Rejection) happen in each of the groups' data. The greater rate of acknowledgment reactions in PakU data may correspond with religious means, where beneficial reactions in apology are highly endorsed. The highest percentage of the reactions, and this is the case in the two groups data, is in the Acceptance classification. One third of the entire reactions, in two groups data, drop into this reaction classification, exposing a relatively high propensity to other-orientedness or self-denying in AR conversation act behaviors. As mentioned by scholars like Hofstede1 (980, 1991), Sawir (2002), Darine and Hall (1998), Kloph (2007) and Rusdi (2000), it is significant to note that two cultures are supposed to be two different nations, "West compared to East", "individualism compared to collectivism", and in contrast, both cultures are said to differ from each other from the perspectives of social and personal harmony. The findings of the current research show that a great number of individuals usually prefer to keep harmony in a relationship, despite the misbehavior of one individual in the scenario that have been mentioned in this study. From linguistic expressions point of view, most reactions are not indicated in the kind of solitude, shown by, "That's OK" or "We will review the issue later", but are a part of a variety of prolonged reactions. The use of additional conversation functions and expressions bear a resemblance to Adrifiza and Jones (2011) AR design, which are classified into main strategies implicating a number of extended expressions. Nonetheless, most AR reactions are intricate and complicated, signaling the respondents' efforts to display indirectness and respect and various feelings. The elaboration, in most of situations, may also be designed to manage face risks being enforced on the addressees. 


\section{Limitations of the Study}

It must be acknowledged that the current study has the following limitations:

First of all, a limited access to native speakers of English restricted this study to a few informants. The study was carried out with thirty (30) British English speakers. The idea of appropriateness can change from culture to culture and from subculture to subculture, and data from such a small sample size might have been insufficient to claim the differences in the AR behavior of British English speakers and Pakistani Urdu speakers. Therefore, the conclusions drawn from the findings of the study might not be valid in British English in general.

Finally, data was collected only from the capital cities (Lahore, Peshawar, Karachi, Quetta, and Islamabad) of provinces of Pakistan and it is also limited to only seven professions (teachers, journalists, academicians, army personals, lawyers, engineers, and doctors). Respondents from a large number of other private and public sector institutions and organization are not included in this study keeping in mind the time constraint and accessibility. Having participants from major cities of all provinces might be used to gain more representative findings from which generalizations could be made.

\section{References}

Adrefiza \& Jones, F. (2013). Investigating apology response strategies in Australian English and Bahasa Indonesia: Gender and cultural perspectives. Australian Review of Applied Linguistics, 36(1), 71.

Adrefiza, A. (2011). Responding to apology: A study of Australian and Indonesian speech act behaviours. (Doctoral dissertation, University of Canberra. Australia).

Afghari, A. (2007). A sociopragmatic study of apology speech act realization patterns in Persian. Speech Communication, 49(3), 177-18.

Agyekum, K. (2006). Apology: a repair mechanism in Akan social interaction. South African Journal of African Languages, 26(2), 53-68.

Agyekum, K. (2015). The Pragmatics of Political Apology in Ghana's Contemporary Politics. Legon Journal of the Humanities, 26(1), 58-79. http://dx.doi.org/10.4314/ljh.v26i1.4

Allami, H., \& Naeimi, A. (2010). A cross-linguistic study of refusals: An analysis of socio-cultural competence development in Iranian EFL learners. Journal of Pragmatics, 43(1), 385-406. https://doi.org/10.1016/j.pragma.2010.07.010

Anderson, L., \& Trudgill, P. (1990). Bad Language. Cambridge: Basil Blackwell Ltd.

Bataineh, R. F., \& Bataineh, R. F. (2008). A cross-cultural comparison of apologies by native speakers of American English and Jordanian Arabic. Journal of Pragmatics, 40(4), 792-821. https://doi.org/10.1016/j.pragma.2008.01.003

Beebe, L. M. (1988). Issues in second language acquisition: Multiple perspectives. Newbury House.

Bennett, M., \& Earwalker, D. (2001). Victim's Responses to Apologies: The Effects of Offender Responsobility.

Bergman, M. L., \& Kasper, G. (1993). Perception and performance in native and nonnative apology. Interlanguage Pragmatics, 4(1), 82-107.

Blum-Kulka, S., House, J., \& Kasper, G. (1989). Cross-cultural pragmatics: Requests and apologies (Vol. 31). Ablex Pub.

Bou-Franch, P. (2012). Pragmatic transfer. The Encyclopedia of Applied Linguistics. https://doi.org/10.1002/9781405198431.wbeal0932

Brown, J. D. (2008). Raters, functions, item types and the dependability of L2 pragmatics tests. In E. A. Soler \& A. Martinez-Flor (Eds.), Investigating pragmatics in foreign language learning, teaching and testing (pp. 224-248).

Brown, P., \& Levinson, S. C. (1978). Universals in language usage: Politeness phenomena. In E. Goody (Ed.), Questions and politeness: Strategies in social interaction (pp. 56-311). Cambridge University Press.

Brown, P., \& Levinson, S. C. (1987). Politeness: Some universals in language usage (Vol. 4). Cambridge University Press.

Canale, M., \& Swain, M. (1980). Theoretical bases of communicative approaches to second language teaching and testing. Applied linguistics, 1,1 . 
Chang, Y. F. (2009). How to say no: An analysis of cross-cultural difference and pragmatic transfer? Language Sciences, 31(4), 477-493. https://doi.org/10.1016/j.langsci.2008.01.002

Cohen, A. D. (2006). Speech Acts. In S. L. McKay \& N. H. Hornberger (Eds.), Sociolinguistics and Language Teaching. New York: Cambridge University Press.

Cohen, A. D., Olshtain, E., \& Rosenstein, D. S. (1986). Advanced EFL apologies: what remains to be learned? International Journal of the Sociology of Language, (62), 51-74.

Darine, C., \& Hall, B. (1998). Culture Shock!. Singapore: Times Books International.

Goffman, E. (1971). Relations in Public: Micro Studies of the Public Order. Harmondsworth: Penguin.

Gorsuch, R. L., \& Hao, J. Y. (1993). Forgiveness: An exploratory factor analysis and its relationships to religious variables. Review of Religious Research, 333-347.

Harris, J. R., \& Robinson, J. A. (Eds.). (2004). The Apology of Aristides: on Behalf of the Christians (Vol. 1). Wipf and Stock Publishers.

Hashemian, M. (2012). Cross-Cultural Differences and Pragmatic Transfer in English and Persian Refusals. Journal of Teaching Language Skills, 4(3), 23-46.

Hofstede, G. (1984). Culture's consequences: International differences in work-related values (Vol. 5). Sage.

Holmes, J. (1990). Apologies in New Zealand English. Language in society, 19(02), 155-199.

Holmes, J. (1995). Men, women and politeness. London: Longman.

Jiang, L. (2015). An Empirical Study on Pragmatic Transfer in Refusal Speech Act Produced by Chinese High School EFL Learners. English Language Teaching, 8(7), 95. http://dx.doi.org/10.5539/elt.v8n7p95

Kasper, G., \& Rose, K. R. (1999). Pragmatics and SLA. Annual review of applied linguistics, 19, 81-104. https://doi.org/10.1017/S0267190599190056

Kitao, S. K., \& Kitao, K. (2014). A corpus-based study of responses to apologies in US English. Journal of Culture and Information Science, 9(2), 1-13.

Lakoff, R. T. (2001). Nine ways of looking at apologies: The necessity for interdisciplinary theory and method in discourse analysis. The handbook of discourse analysis, 199-214

Lakoff, R. T. (2004). Language and woman's place: Text and commentaries (Vol. 3). Oxford University Press, USA.

Liu, D. (1995). Sociocultural transfer and its effect on second language speakers' communication. International Journal of Intercultural Relations, 19(2), 253-265.

Loutfi, A. (2016). Pragmatic Transfer in Moroccan EFL Learners' Requests. Asian Journal of Education and e-Learning, 4(1), 24.

McCullough, M. E. (2000). Forgiveness as human strength: Theory, measurement, and links to well-being. Journal of Social and Clinical Psychology, 19(1), 43-55. https://doi.org/10.1521/jscp.2000.19.1.43

McCullough, M. E., Pargament, K. I., \& Thoresen, C. E. (2000). The psychology of forgiveness: History, conceptual issues, and overview Forgiveness: Theory, research, and practiceed. McCullough, ME Pargament, KI Thoresen, CE New York: Guilford Press.

Montagu, A. (1967). The Anatomy of Swearing. London: Rapp \& Whiting.

Norrick, N. R. (1978). Expressive illocutionary acts. Journal of Pragmatics, 2(3), 277-291. https://doi.org/10.1016/0378-2166(78)90005-X

Olshtain, E., \& Cohen, A. (1983). Apology: A speech act set. Sociolinguistics and language acquisition, 18-35.

Owen, M. (1983). Apologies and remedial interchanges: A study of language use in social interaction. Mouton de Gruyter.

Paltridge, B. (2004). Academic writing. Language teaching, 37(2), 87-105. https://doi.org/10.1017/S0261444804002216

Rahman, T. (1998). Cultural Invasion and Linguistic Politeness Among English-using Pakistanis. Sustainable Development Policy Institute.

Richards, J. C. (1980). Conversation. TESOL Quarterly, 14(4), 413-432. 
Robinson, J. D. (2004). The sequential organization of "explicit" apologies in naturally occurring English. Research on Language and Social Interaction, 37(3), 291-330. https://doi.org/10.1207/s15327973rlsi3703_2

Rusdi. (2000). Information Sequence Structure in Seminar Discussions: A Comparative Study of Indonesian and Australian Students in Academic Settings (Doctoral dissertation, Curtin University of Technology, Australia).

Sapir, E. (1949). Selected writings in language, culture and personality. Berkeley and Los Angeles: University of California Press.

Sawir, E. (2002). Communicating in English across cultures: the strategies and beliefs of adult EFL learners. Doctoral dissertation, Monash University, Faculty of Education.

Searle, J. R. (1975). Indirect speech acts. University of California, Barkley.

Sultana, N., \& Khan, K. (2014). Cultural Effect of Gender on Apology Strategies of Pakistani Undergraduate Students. NUML Journal of Critical Inquiry, 12(2), 24.

Tavakoli, M., \& Shirinbakhsh, S. (2014). Backward Pragmatic Transfer: The Case of Refusals in Persian. International Journal of Society, Culture \& Language, 2(1), 1-24.

Thijittang, S. (2010). A Study of Pragmatic Strategies of English of Thai University Students: Apology Speech Acts. Unpublished doctoral dissertation, University of Tasmania.

Thomas, J. (1983). Cross-cultural pragmatic failure. Applied Linguistics, 4(2), 91-112.

Thomas, J. (1984). Cross-Cultural Discourse as "Unequal Encounter": Towards a Pragmatic Analysis. Applied Linguistics, 5(3), 226-235.

Wannaruk, A. (2008). Pragmatic transfer in Thai EFL refusals. RELC Journal, 39(3), 318-337.

Wei, X. (2009). On negative cultural transfer in communication between Chinese and Americans. Journal of Intercultural Communication, (21).

Whorf, B. L. (1956). Language, thought, and reality: Selected writings. Cambridge, Mass: MIT Press.

Wierzbicka, A. (1994). Semantics, culture, and cognition: Universal human concepts in culture-specific configurations. Oxford University Press.

Wouk, F. (2006). Strategies of apologizing in Lombok Indonesia.

Wu, J., \& Wang, W. (2016). "Apology Accepted": A Cross-Cultural Study of Responses to Apologies by Native Speakers of English and Chinese. International Journal of English Linguistics, 6(2), 63. http://dx.doi.org/10.5539/ijel.v6n2p63

Yarahmadi, A., \& Fathi, S. (2015). A Cross Cultural Study on Iranian EFL Students' Pragmatic Transfer. Procedia—Social and Behavioral Sciences, 192, 498-505. https://doi.org/10.1016/j.sbspro.2015.06.077

\section{Appendix A}

Apology Response (AR) Discourse Completion Test

\section{Part A}

\section{Demographic Information}

\section{Your Name}

\section{Name of Institution}

Profession

Sex: Male Female

Age: years

Nationality:

Native Language:

Rate your speaking ability in English

Excellent Good Fair Poor 
Time spent in English speaking country Months, years. Interaction in English with Native speakers of English in the past

Frequent Occasional Rare Nil Interaction in English with Native speakers of English at present Frequent Occasional Rare

\section{Part B}

\section{Apology Response Scenarios}

\section{Instructions}

Please put yourself in the following situations and assume that in each instance you will have to say something. Write down what you would say in English in the space provided. Make sure you read the whole situation carefully before you respond.

1. At the office, your employ forgot to pass on an urgent letter to you. The next day you complained to your employ that he/she did not pass it to you. He/she says.

Employ: Sorry Sir/Ma'am, I forget to pass it to you. It won't happen again.

You:

2. Your friend promised to return your laptop after a week. However, he/she kept it for almost two weeks. Then you asked your friend to return it. He/she says.

Friend: O' Sorry yar, forgot, really I'll give you tomorrow, promise.

You:

3. You are a junior officer in an organization. Your head forgot to inform you to join the meeting so you missed it because of your head's negligence. Your head talked to you about his fault. He/she says:

Head: I'm really sorry dear; it just skipped out of my mind.

You:

4. You are a senior officer, your junior copied an article from a website for his/her presentation, which you found out. Your junior officer says:

Junior officer: I beg pardon Sir/Ma'am, forgive me this time, and assure you it won't happen again.

5. You were in the hospital. Your senior colleague said he/she will visit you at the hospital but he/she had an urgent business prevented him/her from going. The next day he/she called you to explain why he/she didn't come to see you. He/she says.

Senior: Excuse me dear, my son was not well and I had to take him to hospital, there was no one at home who could take care of her.

You:

6. Having tea with your junior colleague at your house, he/she accidentally spilled tea on your carpet. $\mathrm{He} / \mathrm{she}$ got worried and says:

Junior: Oooops, sorrrry, ooohhh, I spoiled your carpet. Let me help you.

You:

7. You and Abdullah are friends. You lent a camera to Abdullah unfortunately it was damaged. Abdullah says:

Abdullah: I'm extremely sorry buddy, your camera got damaged. But don't worry dude, I'll buy you a new one. You: 
8. In the officer's mess, a senior officer stepped on your foot passing by you. Senior officer says?

Senior officer: Ouch! Sorry dear, I didn't see you coming. Are you OK? Hope I didn't hurt you.

You:

9. You were assigned to do a report with your workmate. You were told to see him at the main door of the meeting room but your workmate came almost half an hour late. The reason of being late was because he missed the first bus. He says:

Workmate: Sorry yar I missed the train. Mom didn't make me to wake up early. And buses you know mostly come late but today came well in time and I was late.

10. You are a senior officer and waiting for a colleague standing beside the corner of a building. Rushing to get to meeting room on time, a junior colleague ran and bumped into you. He /she says:

Junior colleague: I'm sorry, extremely sorry, I beg pardon. Sir, I didn't look at you.

You:

11. At a working place, a colleague stepped foot on you in a crowded elevator. He/she says:

Colleague: Excuse me budz, I was in hurry. You fine?

You:

12. You are a junior officer in an organization, you asked your manager with whom you do not have much interaction, for advice about your presentation for the next meeting. Your manager got late. You were waiting for your manager at the front of his/her office. He/she says:

Manager: Sorry dear, I made you to wait for me. Let's have a discussion.

\section{Appendix B}

Urdu Discourse Completion Test for Pakistani Urdu Speakers
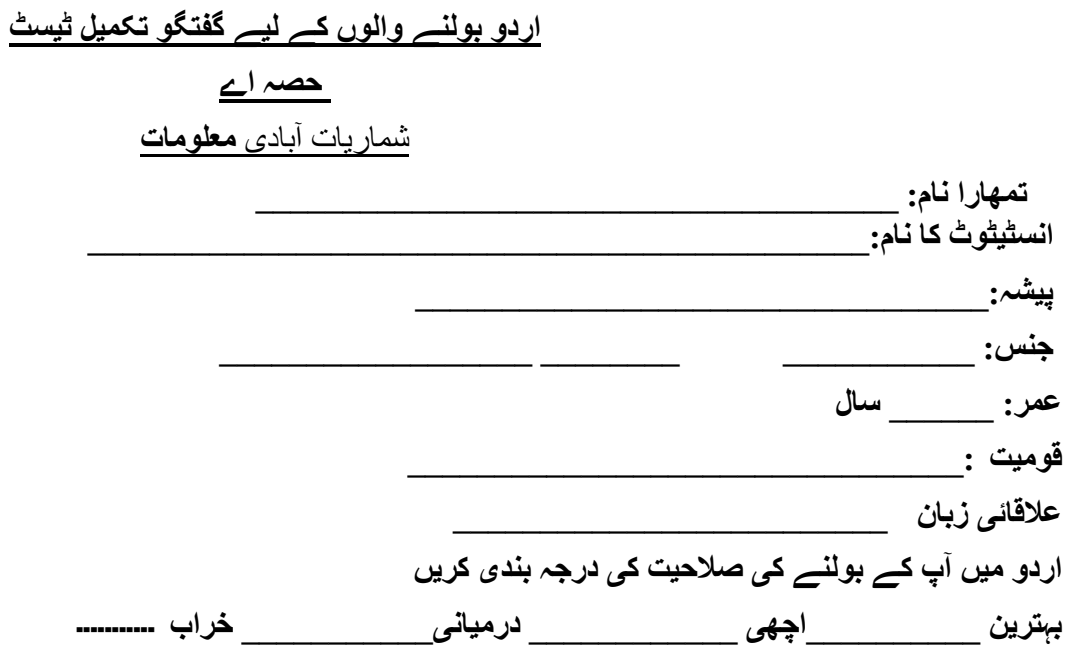


\section{حصس ب \\ معافي قبوليت مناظر}

بايات

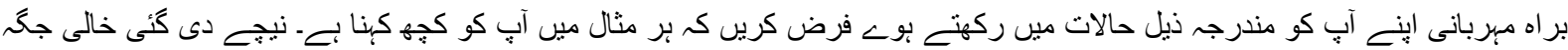

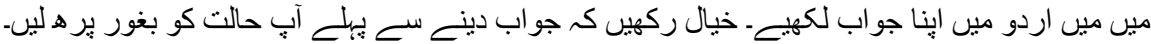

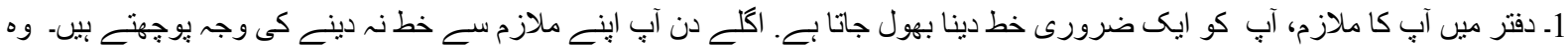

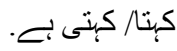
ملازم: معاف كر ديس سر ، ميب آب كو خط منتقل كرنا بهول كيا. اليسا دوباره نبيس بوكا.

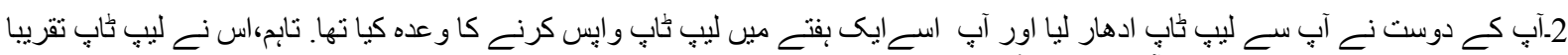

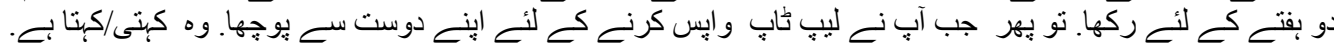

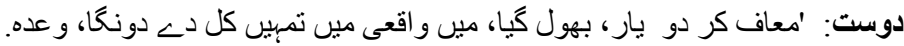
تم:

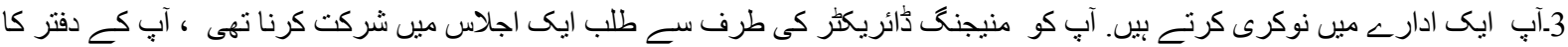

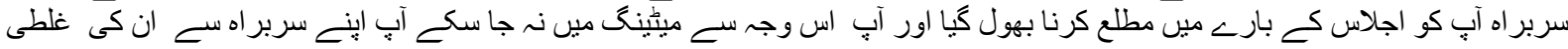

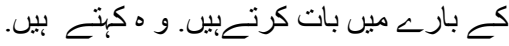

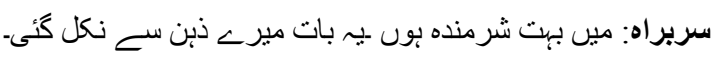

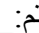

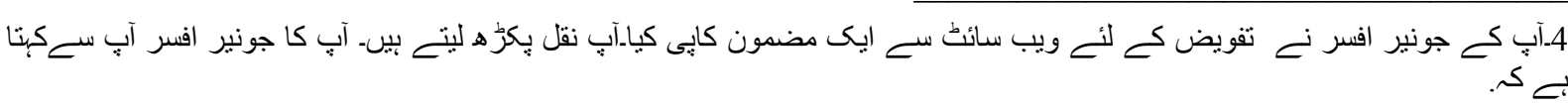
جونير افسر: ميس معافى جا بتا بون سر اس دفع مجهم معاف كر ديس آينده ايسا نبيس بو كا. تم:

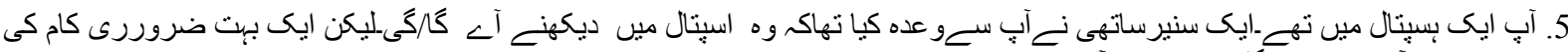

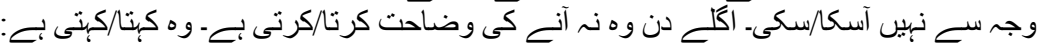

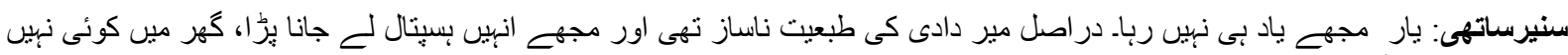
تها جو ان كا خيال ركنا. ثن

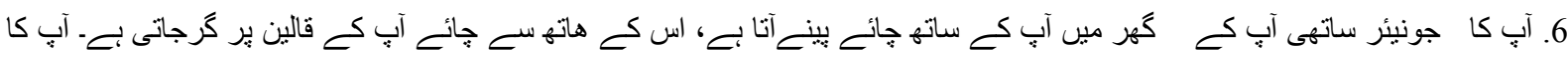
جونيئر ساتهى كهنا هـ جونيئر سناتهى: معافى جابتا بوب، مين نه آب كا قالين خر اب كر ديا. :

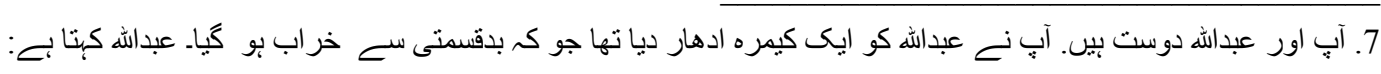
عبدالله: يار ميل بهت شرمنده بوب تمهار ا كميره خر اب بو كيا بـه، ليكن يار فكر نـ كرو، ميس تمهيس ايك نيا خريد دوب كا.

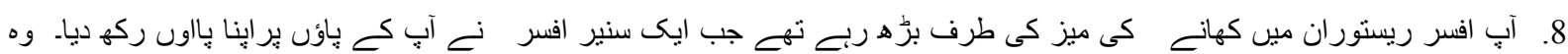

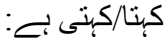

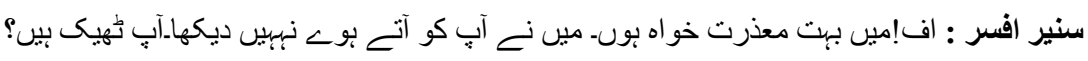




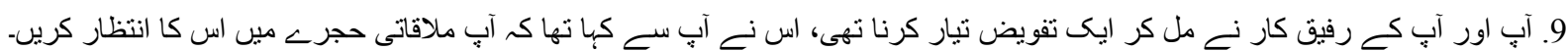

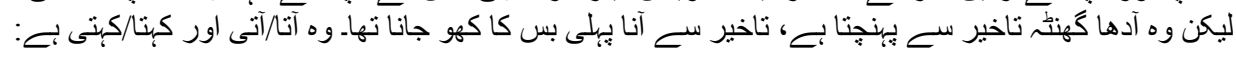

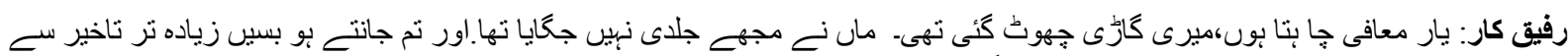

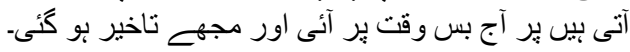

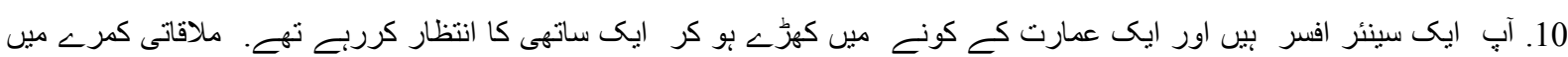

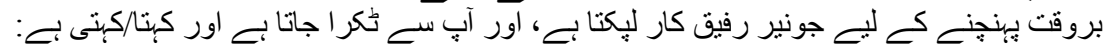

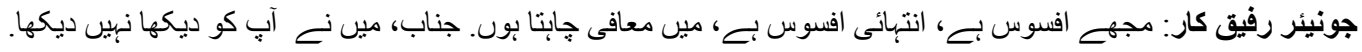

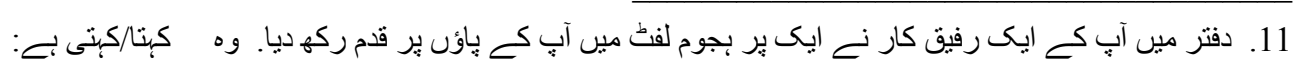

رفيق كار: معاف كرنا يار، مين جلدى مين تها.

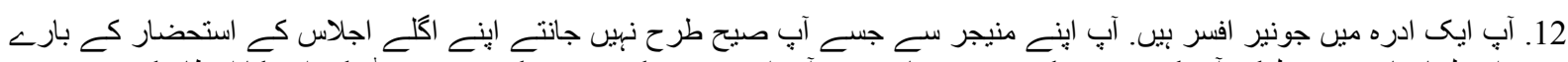

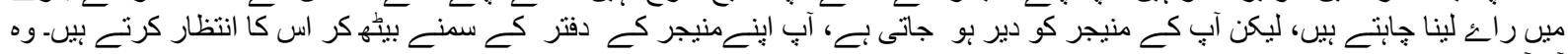

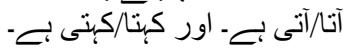

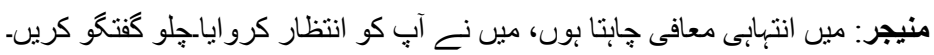
آب:

\section{Copyrights}

Copyright for this article is retained by the author, with first publication rights granted to the journal.

This is an open-access article distributed under the terms and conditions of the Creative Commons Attribution license (http://creativecommons.org/licenses/by/4.0/). 